\title{
Criticisms towards the Idea of Proper Woman in Jessie Burton's The Miniaturist
}

\author{
Theresia Anggarani Wardana \& Ni Luh Putu Rosiandani \\ Department of English Letters, Universitas Sanata Dharma \\ theresia.teko@gmail.com \& puturosi@yahoo.com
}

\begin{abstract}
A discussion about a proper woman always includes the discussion of the concept of separate spheres. In Victorian Age for instance, a proper woman is perfectly described by the term 'Angel in the House'. Seventeenth century Netherlands also expected the same thing for women in that era. The concept of separate spheres along with its expectations of women's proper roles is an example of social construction of gender which defines women. This study is conducted to reveal the criticisms towards the idea of proper woman in The Miniaturist.

The results of this study are: first, women who are considered proper by the society in The Miniaturist have two roles, which are being a wife and being a mother. Moreover, women are also expected to have five characteristics: obedient, powerless, submissive, dependent, and domesticated. Second, The Miniaturist, using the setting in the $17^{\text {th }}$ century Netherlands as a tool to criticize people in the $21^{\text {st }}$ century, tries to redefine the way society thinks, including women, about women's life. The criticisms found in the novel cover four things: criticism towards women's expected roles; criticism towards women's obedience; criticism towards women's powerlessness, submissiveness, and dependence; and criticism towards women's domestication. The text tries to make women more aware of their own value. Women are also suggested to have self-dominion over themselves, and be more critical, independent, and tougher. Society's mindset regarding women's value and capability in the present time is also redefined. The most important thing is the text tries to make people in the $21^{\text {st }}$ century understand women as individuals or persons who have their own right and independence.
\end{abstract}

Keywords: criticism, proper woman,

\section{Introduction}

What is a proper woman? In England's Victorian age, for example, in defining a proper woman, the concept of separate spheres cannot be excluded. Gerard Koot states

it has long been understood that industrial capitalism brought with it an increased separation between places of work and the family home, and that this played a large role in the development of a social ideology and reality of separate and domestic spheres for bourgeois women (2015: 2).

The term 'Angel in the House' then might perfectly describe a proper woman. 'Angel in the House', a title of a popular poem written by Coventry Patmore which reflects his mindset of a perfect wife or woman, became the popular Victorian image of the ideal wife or woman (academic.brooklyn. cuny.edu, 2011). It is not surprising then if a proper woman is the one who is confined to home and expected to be "devoted and submissive to her husband ... passive and powerless, meek, charming, graceful, 
sympathetic, self-sacrificing, pious, and above all-pure" (academic.brooklyn.cuny. edu, 2011).

The separate spheres framework holds that, as Kent in webpage.pace.edu says:

Women inhabited a separate, private sphere, one suitable for the so called inherent qualities of femininity: emotion, passivity, submission, dependence, and selflessness, all derived, it was claimed insistently, form women's sexual and reproductive organization (2003).

Women's being dependent on men resulted in the idea that marriage was the ultimate goal for women. Marriage meant survival in Victorian era. Since the society prevented women from making their own living, there was an inescapable dependence upon men's income (webpage.pace.edu, 2003).

The object of the study, The Miniaturist, takes place in $17^{\text {th }}$ century Netherlands. In fact, the separation of spheres happened in Netherlands earlier than any country, which was in the 17th century (Koot, 2015: 2). Similar to Victorian ideal of women, in the 17th century Netherlands, "the Dutch believed that women were viewed "as the weaker sex who confine their duties to the home while men function in the world at large"'” (Johansen, 2007: 1). Being 'the weaker sex' means that women are dependent to men. It is no wonder that $17^{\text {th }}$ century Dutchwomen also saw marriage as their goal.

The concept of separate spheres along with its expectations of women's roles is socially constructed. The concept is indeed an example of social construction of gender. Women are defined by the society and they should be like what the society expects them to be or in other words a proper woman, or for Patmore, 'Angel in the House'.

Burton's debut novel, The Miniaturist, has been chosen as the object of the study. The novel provides interesting criticisms towards the idea of proper woman, mainly through its female characters. The setting in 17 th century is used as a tool to criticize the $21^{\text {st }}$ century in which women are still defined by the society. The focus of this study is on examining thoroughly the depiction of proper woman through the female characters in the novel and analyzing the criticisms addressed towards the idea of proper woman. Feminist criticism is used as the approach of the study.

Feminist criticism is unique because, as Bressler puts it, it is more "divided than unified, housing more internal disagreements..." (1999: 188), which means it consists of a variety of feminist theories. Nonetheless, feminism has a set of principles uniting the differences: feminist critics declare that "women are people in their own right, they are not incomplete or inferior to men" (Bressler, 1999: 189). Feminist critics include many literary schools such as historical and psychoanalytic to increase people's understanding of women's experience in the past and present and also to promote people's appreciation of the value of women in the world. The practice of feminist criticism typically involves examining how the gender roles of literary work reflect or subvert the 'traditional' gender roles (Millikan, 2011).

\section{Proper Woman in the $17^{\text {th }}$ Century Dutch Society in The Miniaturist}

De Beauvoir says that "one is not born but rather becomes a woman" (Humm, 1990: 238). In other words, being a woman is something that one learns. The identity of a woman is socially constructed. Society demands her to behave and live her life like what is considered to be proper.

Nella, Nella's mother, and Marin are the three female characters analyzed in order to figure out the depiction of proper woman. The explanation is divided into two elements: the meaning of proper woman seen as women's roles and the meaning of proper woman seen as characteristics or qualities expected by the society. 


\section{Women's Roles}

Words 'proper woman' are repeatedly mentioned in the novel, especially by the main character, Nella. There are two criteria of being proper woman, as it is clearly stated by her, that "a proper woman marries-she has children" (161). These criteria are the roles expected from every woman in the society.

\section{a. Wife}

In the very beginning of the story, Nella is very enthusiastic about becoming a wife in Amsterdam. For her, becoming a wife equals getting a new life as a woman. Her mindset of proper woman is given by her mother who keeps telling her the importance of getting married, specifically to a man who can keep a guilder in his purse" (17).Moreover, according to her mother, "life is hard if you're not a wife" (22).

At first, Nella is quite shocked with her mother's blunt statements, she even questions her mother. Not only that, she even feels the urge of escaping her village. Yet in the end, she does what is told anyway, as she "concerned about her mother's nerves just enough not to rebel" (18). Therefore, when Johannes Brandt, a wealthy merchant, asks for her hand, she gladly accepts him, because, as Nella says herself, being a wife is the only option she has in life. This statement implies that being a wife is the fate of women. Then, it becomes Nella's goal to be a proper woman. It can be seen from her attempt to practice being a lady for two years-she tries to walk like a lady and wears a newly tightened corset.

\section{b. Mother}

After a woman becomes a wife, another requirement of becoming a proper woman is having children or in other words being a mother. When her mother tells her to marry a rich man, Nella once says that she does not have anything to give him in return. Her mother surprisingly replies "look at you. What else do we women have?" (17). Implicitly, her mother tells Nella that women only have their body to be 'offered' to men. Nella indeed does grieve because of her mother's statement and feel that she is 'reduced' as a woman by her own mother. From her mother's statement, it can be said that her existence as a woman is simplified. Nella's existence, or women's existence in general, is merely for the purpose of procreation. Therefore, commenting Nella's first menstruation, her mother says that the purpose of that blood is "the security of children" (23) or a promise of motherhood. Nella fails to see how it is possible to feel secure if she has to experience labour pains which sometimes lead several women to death. When Nella refuses to be that kind of wife, her mother says there is no other kind of wife. She states that Nella's body is the key, while patting Nella's stomach. So, a woman may function well if she can produce children.

\section{Women's Characteristics}

Through Nella and her mother, it can be seen how women are expected to live their life in the society. The society's expectation towards women is described through Nella's mother, who keeps telling her that women's roles are to be a wife and to be a mother. That is the idea of proper woman, which is an "internalised norms of femininity" (Gamble, 2006: 3) found in the Dutch society in the novel. The idea already becomes the part of the society, the part in which they think or behave. However, talking about being a proper woman is not only about the roles of being a wife and a mother. It also involves characteristics or qualities expected from the society. The appropriate characteristics of women in the $17^{\text {th }}$ century Dutch society in the novel are obedient, powerless, submissive, dependent, and domesticated.

\section{a. Obedient}

Social construction of gender is learned through many aspects of society. In Nella's case, she learns it from her parents, especially her mother. Nella's obedience is related to her reaction towards idea of proper woman given by her mother. Nella, at first, questions the idea of proper woman given by her mother-even she feels the urge of escaping her village when she practices being a lady. Up to this point, her 'little 
rebellion' can be seen. 'Little rebellion' here means there is a small part of Nella that rejects the idea of proper woman. This 'rebellion' is weak since Nella does not entirely disobey her mother. Yet, it stops at that point because at the end, Nella chooses to believe what her mother says since she concerns about her mother's nerves. It results in Nella's accepting the idea of proper woman and she clings tightly to this idea, which can be seen from how she perceives her marriage with Johannes and her life as a woman. In other words, she obeys the social construction of gender by accepting the idea of proper woman. In addition, Nella's obeying what her mother says also implies her naivety, since her decision to obey her mother lacks careful consideration. She believes her mother always tells her the truth, including the idea of proper woman, without giving any thoughtful consideration.

\section{b. Powerless}

In the novel, women have less power than men for, as Wilson states, "men hold power in all the important institutions of society" (2000: 1494). Since they have less power, it is not surprising that they are willingly married, as marriage is believed as "the only possible form of influence a woman may have" (317) and a way-or the 'only' way to increase woman's power. Moreover, Marin's statement that says

we can do nothing, Petronella-we women ... some of us can work ... backbreaking work, for which they won't even pay us half of what a man could earn. But we can't own property, we can't take a case to court. The only thing they think we can do is produce children who then become the property of our husbands (160)

implies the powerlessness women have in their lives. From Marin's statement, women's important role is only on procreation and the rest, they are powerless.

In the novel, women's powerlessness is also seen in Nella's reaction towards the first note the miniaturist sends read: every woman is the architect of her own fortune. She is confused with it because she thinks “women don't build anything, let alone their own fates. All our fates are in the hands of God, and women's in particular, after their husbands have passed them through their fingers ..." (76). Nella's reaction conveys that women are entirely powerless to the extent that they cannot have their own lives without men's interference. Their fates lie in their husbands' hands. It is not surprising as it is widely believed in the novel that "men are the makers of the world" (289). As the word 'makers' suggests, men undoubtedly hold power in the society.

\section{c. Submissive}

Women's mindset that they are not the owner of their own fates also implies their submissiveness to men. The very fact that they let men have their fates shows they willingly accept men's authority in their life. They admit the idea as if it were natural. It is similar with what Tong states in her book that in patriarchal society, cultural constructions are considered natural and being a normal person means one is able to show their gender identity and behavior based on their biological sex (Tong, 2009: 51). In other words, the idea is already internalized in women's mind. Therefore, the miniaturist's first note is not 'natural' since it differs from what is constructed in the society, much to Nella's confusion.

\section{d. Dependent}

Women's being powerless always eventually leads to another problem, which is their dependence upon men. Women's dependence can be seen from the fact that marriage is the ultimate goal for women. Indeed, since a proper woman marries and becomes a mother, it implies that women need men in order to be a proper or perfect woman. As they are not prepared to work, women need security in order to survive their life. Security here means protection against poverty. Nella needs security from a wealthy merchant in order to survive from her 'previous' life, which is covered with her father's debt. "You'll have a roof over your head, thanks be to God" (30), Nella's mother once says to Nella. It also can be seen from 
Marin's statement that Nella's purpose of marrying a merchant is due to the need of having a secure life. It means women are financially dependent on men.

Besides financial dependence, women are also dependent on men in order to have authority. It is widely believed by many women in the novel, including Nella and her mother, that "... [marriage is] the only possible form of influence a woman may have. Marriage is supposed to ... increase a woman's power" (317). Nella wants to make Amsterdam her own, considering the fact that Johannes is an influential and charismatic merchant in Amsterdam. In the novel, an example of power women may have if they get married is having household to run, because commonly a household can only be obtained when a woman is a wife or a widow (315).

\section{d. Domesticated}

To be a wife means a woman becomes the mistress of the household. Yet, it cannot be defined as simple as that. She as a wife has the authority of the household and, as stated earlier, this kind of authority is what a woman can dream of. It likely refers to Janeway's argument which states about women's agreement about exchanging private power in return for public submission. Men rule the public domain, while domestic sphere is under women's authority (Eisenstein, 1984: 10). Nella's job as Johannes' wife is to become the mistress of the household whose job is "keeping us [people living in Brandt's house] all in order" (174). The fact that women can only rule the domestic sphere or the household means the idea of separate spheres exists in the society in The Miniaturist.

The idea of separate spheres not only can be seen through Nella, but also from another female character, Marin. As her brother works in VOC (Vereenigde OostIndische Compagnie), Marin seems to know about the inside and outside of the VOC (29). Nella is rather surprised finding out about this fact, she even thinks that "Johannes is surely crossing a forbidden boundary" (29) as he seems to let his sister know about his works. From Nella's thought it can be concluded that outside world is, in fact, not women's business. Nonetheless, in spite of her interference in Johannes' work, she still is not allowed to work just like her brother because, as a woman, she should remain at home. Another proof can be found from what Nella's father says about women who work together with men: "it is a good thing that ladies no longer sail so much. Women on board bring bad luck" (53). His words also reflect the current society's belief that women should stay at home, that women should know their place. Nella's mother agrees with her husband and adds, "they [women] only bring the luck men give them" (53). Women are also prohibited to come and visit their husbands' workplace. The guards at VOC workplace prevent Nella to visit her husband. Moreover, a wife cannot go to her husband's warehouse unannounced. Nella describes Brandt's warehouse as "her husband's domain" (298), indicating it is not hers.

\section{The Criticism towards the Idea of Proper Woman}

\begin{abstract}
Johannes describes the $17^{\text {th }}$ century Dutch society in the novel as an invisible cage ... [which makes] any person's behaviour mutate under such constant scrutiny, such bigoted piety-neighbours watching neighbours, twisting ropes to bind us all ... Well, it's a prison (264).
\end{abstract}

The society always watches what each person does and judges whether it is appropriate or not. Therefore, it in a way binds everyone, including women who are bound to the idea of proper woman which make them have no freedom over their life.

The Miniaturist tries to criticize the idea of proper woman which restricts women's lives. However, before the criticisms are analyzed, it is important to figure out to whom the criticisms are actually addressed. Burton stated herself that she "wasn't drawn to a historic setting in order to set up the issue of a rounder female character..." (Lee, $n, d$.). It means that the setting is not the focus of her novel. Her focus is that she wants to 
create female characters who "for once are not defined by any other ideal than that they are human" (Lee, n,d.). From those statements, it can be said that the concerns of the criticisms are directed to people in the $21^{\text {st }}$ century. The setting in the $17^{\text {th }}$ century Netherlands is used as a tool to criticize the social construction of gender which still binds women in the $21^{\text {st }}$ century. The Miniaturist wants to show that the idea of proper woman or, in other words the social construction of gender, still exist today-a situation which is not very different from the $17^{\text {th }}$ century. The criticisms are not only addressed to the society, but also to women themselves who are still chained by the social construction of gender. Through the female characters, the text tries to redefine the way people think about women and also the way women think about their own value. It has the same purpose with feminist critics who want to "promote people's appreciation of the value of women in the world" (Millikan, 2011).

\section{Criticism towards Women's Expected Roles}

The society's demands regarding women's roles are voiced through Nella's mother. The $17^{\text {th }}$ century Dutch society in the novel defines women's life by assigning the roles of being a wife and a mother. However, these roles in other words give no freedom to women. Women lose their self-dominion as they cannot decide what kind of life they have by themselves. The Miniaturist criticizes the way of thinking about women's expected roles. In delivering the criticism, it employs two ways of criticizing: first, through Nella's unexpected marriage life and second, through Marin's mindset about being a wife. Nella comes to Brandt's house with high hopes to become a merchant's wife. Ironically, it turns out her marriage is not like what her mother says. She is untouched by Johannes even though she wishes to immediately do her proper role as a wife and have children. It is not that kind of marriage which her mother tells her-the "ideas of true love, of marriage beds, laughter, and children" (110). The security of life she seeks in marriage cannot be obtained as she finds out that Johannes is often slack in his works which, eventually, results in his having no money left. Moreover, Marin holds the authority of the household, another thing Nella pursues. Its climax is when she finds out that her husband is a gay which undoubtedly seals away the promise of motherhood. After the revelation concerning the idea of proper woman comes to her, she realizes that she has pulled her wings off. She even thinks "for some of us, it's a waste to be married" (399). The text shows the importance of having independence as a person or self-dominion. Women should have their own decision regarding their lives.

When Marin is still young, she makes a brave decision of not being married. She does not want to live her life under the authority of a man since she "couldn't tolerate being a wife" (316). She thinks that as a single woman she already has a household without being a wife and she can interfere in Johannes' works. This means everything to her-especially her capability of interfering with her brother's works in which she is very interested in-she even considers it as a freedom. She does not want to give up who she is and what she has (315). If she gives up on her current life and lives as a wife, she will lose her freedom as she will live under the authority of her husband. Indeed, Marin is an interesting female character in this novel. Even in her youth, she shows selfdominion-a thing which is rarely found in women's characteristic in that time. The idea of feminism is reflected through this character. She shows the independence as a person. Society does not define her existence as a woman. She, in this context, is free.

Nella's unexpected marriage life and Marin's way of thinking can also be interpreted as the text's way of mocking the idea of proper woman. The unexpected marriage life of Nella implies that the idea is indeed foolish and makes no sense. There is no way an idea like that can guarantee women's life to be perfect. The text also uses Marin as a character to show its mockery towards the idea of proper woman. When Nella states that a proper woman marries and has children, Marin gives an interesting 
comment: "Then what does that make me? Am I not a proper woman? Last time I looked I certainly was" (161). Marin has a different opinion about the word 'proper'. She identifies 'proper woman' based on the biological appearance of a woman, a female human being. Her comment implies that the social construction of gender which assigns women to do proper role does not define a woman.

\section{Criticism towards Women's Obedience}

The Miniaturist criticizes women's obedience in accepting the idea of proper woman. Nella is the character used as an example of a woman who willingly obey the society's expectation or in other words, the social construction of gender. The text tries to redefine this way of thinking by showing Nella's marriage life and how she looks like a fool to believe in such idea.

Another way the text uses to show its criticism is by showing the importance of having critical thinking. It is presented through Nella's action when she buys Christmas presents for her family. When she tries to find the perfect gift for her little sister, Arabella, she thinks her sister will love to have finest Christmas biscuits. "... but better, she thinks, that Arabella should have a book and learn a little" (195). Nella tells herself that "you wouldn't have thought such a thing back in August" (195), implying that back in August, she does not feel the necessity of learning as she only focuses on becoming a wealthy merchant's wife. Her intention to buy a book for Arabella means she thinks her little sister needs to have wider knowledge, so that she will be more critical about deciding what kind of life she really wants. Nella does not want her little sister to willingly accept the idea of proper woman.

\section{Criticism towards Women's Powerlessness, Submissiveness, and Dependence}

The text criticizes women's powerlessness, submissiveness, and dependence since women, again in this context, are defined by ideals made by the society. The criticism is directly addressed to women themselves.
Women's submissiveness to this idea implies the absence of self-dominion in women's life as they believe their fate belongs to men and also the lack of struggle or willpower in women's life. The mindset makes women dependent since men hold their fate. This results in their accepting men's domination with resignation. The text tries to redefine the way women think about their fate by employing two things: first, through the existence of the miniaturist and her notes, and second, through Nella's action influenced by the miniaturist.

\section{a. The Miniaturist and Her Notes}

The miniaturist is a character who holds the important key of Nella's mindset changing. Nella has the first contact with the miniaturist when she orders some miniatures to furnish her wedding gift from her husband, a cabinet-sized replica of their home. Along with miniatures, she sends notes which bring out Nella's self-awareness. Through these notes, the mindset of women's fate is redefined.

The first note says that "every woman is the architect of her own fortune". There is a contradiction between the popular mindset about fate and this miniaturist's note. The miniaturist rejects the former and tries to tell Nella that the current belief that women have no authority over her fate is wrong. Through this notes, she states that every woman is the creator of her own fate. The miniaturist wants Nella to rethink about her self-dominion which indeed is pulled off by the idea of proper woman.

After telling Nella that women's fates lie on their own hands, she sends the second and third note- "I fight to emerge" and "things can change", respectively. As their fates belong to them, they should fight for their own life instead of depending on men. The miniaturist, through her notes, encourages Nella to fight for her life because things can change.

The fourth note says "NELLA: THE TURNIP CANNOT THRIVE IN THE TULIP'S PATCH OF SOIL". It is directly stated in the novel that turnip and tulip are completely 
different plants-"one practical and simple in its structure, the other decorative and engineered by man" (226). Through the miniaturist's note, the symbolism of turnip and tulip is used. A 'turnip' woman is practical which means that she fights and deals with the real situation rather than clinging to idea of proper woman. A 'tulip' woman, who likely refers to a proper woman, is 'engineered' by man. It means her life is being controlled by men. She is dependent to be able to live. The 'decorative' word in 'tulip' woman may refer to its function which serves eye's pleasure. Since she follows the rule and she has the attitudes expected from her as a woman, the society sees her as a pleasure. The 'turnip' woman, on the contrary, is 'simple'. Turnip is a plant which grows out of sight, so it has no decorative function. However, it nourishes its body inside the soil. A 'turnip' woman gives no pleasure to the society. Yet inside she has a quality which the 'tulip' woman lacks: self-dominion. The 'turnip' is critical, independent, strong-willed and not defined by anything else except herself. 'The soil' may refer to mindset or way of thinking. The 'tulip' woman grows in the society where she is taught to be an ideal woman based on the society's perspective. The 'turnip', therefore, cannot fully develop in the 'soil' in which the 'tulip' grows. The point of the fourth note is that, with such different characteristics with a proper woman, the 'turnip' will not be able to grow if she follows the idea of a proper woman like what the society expects them to. The miniaturist conveys that Nella has to leave behind her mindset about proper woman because each woman has their own selfdominion.

The miniaturist's characteristics are similar with Marin in a way that they are women who are not defined by the ideals from the society. The miniaturist in particular, with her notes and behaviors, is a character whose purpose is to free women caged by the idea of proper woman.

\section{b. Nella's Actions}

With her marriage life goes unexpectedly wrong and, especially, with the influence of the miniaturist's words in her life, Nella changes her mind regarding the idea of proper woman. From her actions, it can be seen that she has taken back her selfdominion which previously has been lost because of the idea of proper woman. There are three actions which show her selfdominion: her action regarding Meermans' sugar, her action concerning Thea, Marin's illegitimate daughter, and her action about her dependence on the miniaturist.

Johannes is imprisoned while leaving behind his unfinished business regarding selling Meermans' sugar. Marin is incapable of doing something about it since she is pregnant with an illegitimate child. The only one who can save Brandt's family name and wealth is Nella. With her new mindset that her fates lie in her own hands, she fights to emerge from this difficult situation. She no longer shows the lack of self-dominion which makes her accept her fate with resignation. She believes that things will change if she does something about it. Her struggle pays off since she is able to sell the sugar, all by herself.

Nella's self-dominion also can be seen through her decision regarding Marin's illegitimate daughter, Thea. Marin dies after delivering her daughter. This exacerbates the current situation Nella faces as it will certainly difficult for her to raise an illegitimate child. However, she positions herself as the answer of the current situation. "We must endure. For Thea's sake, we must emerge from this" (389). It means that whatever she does, it will determine how things will end up. She expresses selfdominion since she struggles and fights for her life.

Nonetheless, Nella's self-dominion reaches its climax when she decides to stop depending on the miniaturist. The miniaturist indeed has a big role in Nella's life. She guides Nella to find her selfdominion. This results in Nella's dependence on the miniaturist's guidance. However, at the end of the story, she decides to stop relying on the miniaturist and start depending on herself. Nella's full selfdominion is symbolized by her breaking 
down the cabinet house and its miniatures, the things which bring the miniaturist into contact with her. This symbolizes the end of the miniaturist's involvement in Nella's life as she starts her life anew as an independent woman.

Through both the miniaturist's mindset seen in her notes and Nella's actions influenced by the miniaturist, the idea of women's empowerment is applied to criticize their submissiveness, powerlessness, and dependence. The miniaturist's way of thinking empowers Nella as a woman to have more control in her own life and confidence when facing the difficult situation she is in. Through the idea of women's empowerment applied in the novel, the idea of feminism is reflected. Again, it is about women's independence as persons. The text voices women's authority over her own self.

\section{Criticism towards Women's Domestication}

Since social construction restricts women's domain, in other words it limits women's freedom. Moreover, women's domestication also means the limitation of women's potential. As Wollstonecraft suggests, women are prepared to get married and be a good wife. They are not trained to work like men, so they "have no other scheme to sharpen their faculties" (Wollstonecraft, 1793: 61). This situation is reflected through Nella who, when she still lives in her village, is prepared to be a good wife. In the novel, no men are interested in training women. Women are not given the same opportunities as men to sharpen their faculties. The text rejects the mindset regarding women's domestication as it restricts women's freedom as well as their potential. It tries to redefine the way people think by using two women characters in her novel, Marin and Nella.

Marin knows the in and out about Johannes' work in VOC. Marin indeed has fascination with her brother's work. Her room is full with things her brother brings home from journeys. Those are indeed uncommon things for a woman in that time to have-even Nella comments that "this room is not from Amsterdam, though it shows an Amsterdammer's drive for acquisition. This is the republic's reach, in four small walls" (51). However, it implies something more important: her incapability of having men's job. The society believes that women on board bring bad luck. This statement, the writer argues, is a manifestation of the concept of separate spheres which restricts women to remain at home. It also shows the implication of the subordination of women's interests. This kind of mindset limits women's true potential, including Marin. Besides studying the things Johannes brings home for her, she masters snippets concerning her brother's work as a merchant-those of tobacco sales, silk and coffee, for example. She often gives advices to Johannes about his work and reminds him to work diligently. Yet, Marin only can go as far as that. She cannot go further as she is bound to the concept of separate spheres.

Nella is used to show women's capability in doing what is considered as men's job. What makes her different from Marin is that she has the opportunity to do it. As stated previously, Nella is the one who can successfully sell Meermans' sugar. This action, besides implying Nella's selfdominion, conveys another important fact: she is able to cross the boundary of the separate spheres. She makes a brave decision to violate the rule and cross the boundary of separate spheres. Not only that, she cleverly decides to whom she sells the sugar after carefully considering the situation. At first, she feels unconfident when she knows she has to bargain as a part of selling the sugar. It turns out she can do it very well, even Arnoud Maakvrede, the confectioner to whom Nella sells the sugar, is impressed with Nella's ability of bargaining. With her skill, she has the potential to become a good merchant as good as her husband.

Through these two characters, The Miniaturist tries to redefine the mindset in the society that women's characteristics make women incapable of functioning in the public realm, so that they are best suited in the domestic sphere (Hughes, $\underline{\text { n.d.). }}$. Through 
Marin, the text shows that women are also capable of doing men's job if given the opportunities of doing so. Nella proves that she is able of doing men's job very well in spite of the fact that she is a woman. The belief that women are not allowed to go into men's domain is destroyed through Nella's action which proves that it is not impossible to cross the boundary of separate sphere. The criticism reflects the idea of feminism which desires equal rights and equal opportunities for women. It shows that with equal rights and opportunities, women have the same potential as men in public domain. Through Marin and Nella, The Miniaturist also wants to make women aware about their value. Women should not think that they are less competent than men.

\section{Conclusion}

In order to dissect the depiction of a proper woman in the $17^{\text {th }}$ century Dutch society in The Miniaturist, the roles and characteristics of women which are considered proper are analyzed. Women are expected to fulfill two roles in their life, which are to be a wife and a mother.Besides fulfilling the roles of being a wife and a mother, women in the $17^{\text {th }}$ century Dutch society in the novel are also expected to have the appropriate characteristics: obedient, powerless, submissive, dependent, and domesticated.Using the setting in $17^{\text {th }}$ century Dutch society as a tool, The Miniaturist criticizes society's mindset, including women's in the $21^{\text {st }}$ century which are still chained by the social construction of gender. The text criticizes four things: women's expected roles; women's obedience; women's submissiveness, powerlessness, and submissiveness; and women's domestication.

The Miniaturist encourages women to recognize their own value, to have selfdominion over themselves, and to be more critical, independent, and tougher. The text also tries to redefine society's way of thinking regarding women's value and capability. Above all else, the text tries to make people in the $21^{\text {st }}$ century understand women as individuals or persons who have their own right and independence.

\section{References}

Bressler, Charles E. Literary Criticism: An Introduction to Theory and Practice. $2^{\text {nd }}$ ed. New Jersey: Prentice Hall, 1999.

Burton, Jessie. The Miniaturist. London: Picador, 2015

Eisenstein, Hester. Contemporary Feminist Thought. Boston: G. K. Hall \& Co., 1983.

"Historical Analysis: Women as "the Sex" During the Victorian Era". Victorian Women: The Gender of Oppression. n.p. n.d.(webpage.pace.edu/nreagin/tempmot herhood/fall2003/3/HisPage.html).

September 1, 2015.

Hodgson-Wright, Stephanie. "Early Feminism". n.d.The Routledge Companion to Feminism and Postfeminism. ed. Gamble, Sarah. New York: Taylor \& Francis eLibrary, 2006: pp 3-14.

Humm, Maggie. The Dictionary of Feminist Theory. Columbus: Ohio State University Press, 1990.

Johansen, Brenda. "Nit-Picking in the Golden Age of Dutch Art". 2007. (http://www1.umassd.edu/euro/semina rpapers.cfm). August 31, 2015.

Koot, Gerard. The Portrayal of Women in Dutch Art of the Dutch Golden Age: Courtship, Marriage and Old Age. Dartmouth: University of Massachusetts, 2015.

Lee, Richard. "Richard Lee talks to Jessie Burton, star debut author at the London Book Fair". Historical Novel Society. n.p. n.d. 
(historicalnovelsociety.org/richard-leetalks-to-jessie-burton-star-debut-authorat-the-london-book-fair/). October 14, 2015.

Millikan, Lauren. "The Feminist Approach". The Evolution of Alice Criticism. Carleton College. February 24, 2011. (http://www.carleton.edu/departments/ ENGL/Alice/CritFem1.html). July 18, 2016.

The Angel in the House.William Makepeace Thackeray. n.p. March 2, 2011. (http://academic.brooklyn.cuny.edu/engl ish/melani/novel_19c/thackeray/angel.h tml). September 2, 2015.

Tong, Rosemarie. Feminist Thought: A More Comprehensive Introduction. $3^{\text {rd }}$ ed. Colorado: Westview Press, 2009.

Wilson, Ara. PATRIARCHY: Feminist Theory. n.d.Routledge International Encyclopedia of Women: Global Women's Issues and Knowledge. Eds.Cheris Kramarae \& Dale Spender. New York: Routledge, 2000: pp. 1493-1497

Wollstonecraft, Mary. A Vindication of the Rights of Woman: with Strictures on Political and Moral Subjects. Dublin: J. Stockdale, 1793. 